\title{
CONSTRUCTION OF TWO NEW BREAKWATERS AT OSTEND LEADING TO AN IMPROVED HARBOUR ACCESS
}

\author{
Hadewych Verhaeghe ${ }^{1}$, Luc Van Damme ${ }^{1}$, Jan Goemaere ${ }^{1}$, \\ Julien De Rouck ${ }^{2}$, Wim Van Alboom ${ }^{3}$
}

\begin{abstract}
The need of an improved harbour access resulted into the design of two new breakwaters in Ostend. The construction of the new breakwaters fits within the Integrated Coastal and Maritime Plan for Ostend. This paper describes the history, the extensive studies, the architecture and the construction works of the breakwaters. Finally future developments are considered.
\end{abstract}

Keywords: rubble-mound breakwater; harbour access; breakwater design

\section{INTRODUCTION}

Ostend is situated in the middle of the Belgian coastline. Although for many centuries Ostend was one of the most important ports at the Southern North Sea, it has a relatively small harbour. In order to make the harbour accessible for ships with a length up to $200 \mathrm{~m}$, important modification works of the harbour access were necessary. Studies have led to a new design of the harbour access in which the old (curved) access defined by two wooden piers is replaced by a new access channel perpendicular to the coast line together with the construction of two breakwaters (Fig. 1).
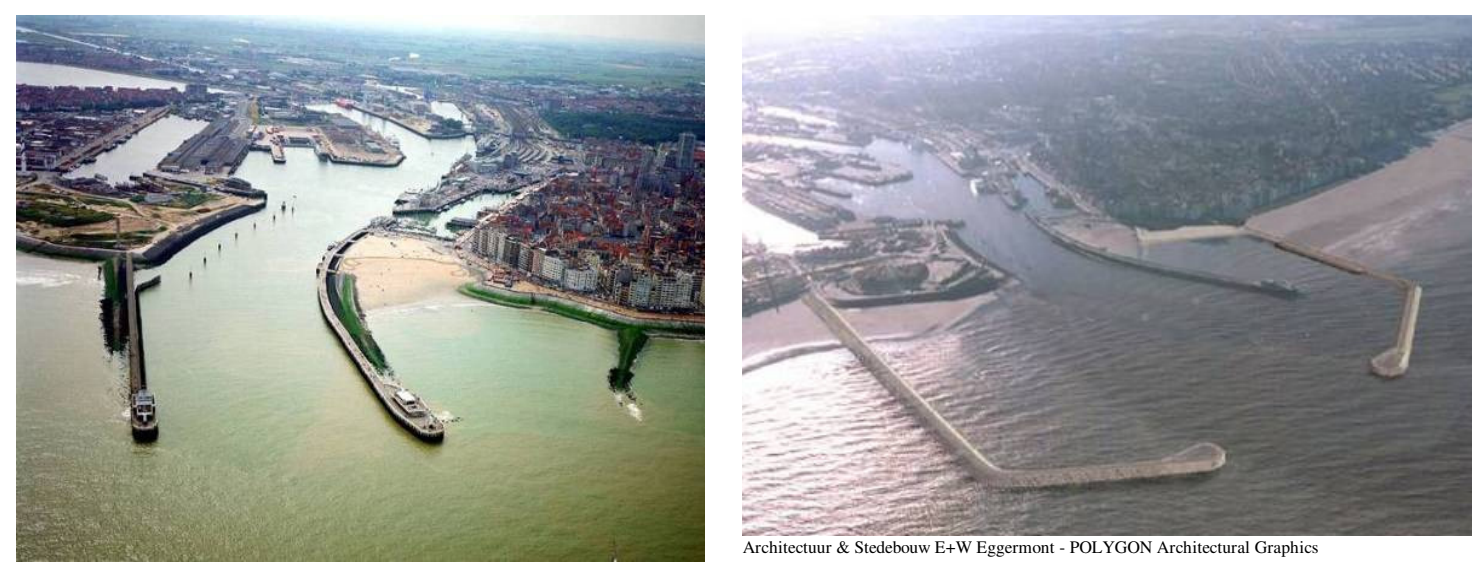

Figure 1. Old harbour access defined by two wooden piers (left) - New harbour access with access channel perpendicular to the coast and two new breakwaters (right).

\section{DESIGN OF THE NEW HARBOUR ENTRANCE WITH TWO NEW BREAKWATERS}

\section{Integrated Coastal and Maritime Plan for Ostend}

The design of the new Ostend harbour entrance is a part of the major 'Integrated Coastal and Maritime Plan for Ostend' of the Flemish Community. The objectives of this plan are:

- to protect the city of Ostend against flooding : the maximum allowable overtopping discharge for a storm with return period $\mathrm{R}=1000$ year is $1 \mathrm{l} / \mathrm{s} / \mathrm{m}$;

- to make the harbour of Ostend accessible for larger ships : access for ships with lengths up to $200 \mathrm{~m}$ is required;

- to approach the harbour expansion and coast protection in an integrated way.

The Integrated Coastal and Maritime Plan for Ostend consists of the following five project items:

- coastal protection of Ostend city

- renovation of 'Albert I - promenade' and 'Zeeheldenplein'

\footnotetext{
${ }^{1}$ Flemish Community, Department Mobility and Public Works, Maritime Access Division, Coastal Division, Vrijhavenstraat 3, B - 8400 Oostende, Belgium

${ }^{2}$ Department of Civil Engineering, Ghent University, Technologiepark 904, B - 9052 Zwijnaarde, Belgium

${ }^{3}$ SECO, International Department, Aarlenstraat 53, B - 2040 Brussel, Belgium
} 
- integrated coastal zone management, 'Oosteroever'

- safety measures against flooding through the harbour

- improving harbour access of Ostend

Fig. 2 shows a picture of the seadike of Ostend as it was before 2003. At that moment the risk of flooding of the city centre was too high and the stability of the dike was not guaranteed. Beach nourishment has been performed (and is planned) to increase the safety of Ostend city. The final beach nourishment will provide safety against the 1000-year storm.

The construction of the two new breakwaters at Ostend, fits in the project item of improving the harbour access of Ostend'. Fig. 3, left, shows a navigation simulation of a ship entering the harbour of Ostend as it was before improving the harbour access. It is clear that entering the harbour was a delicate operation. Fig. 3, right, shows the damage to the western

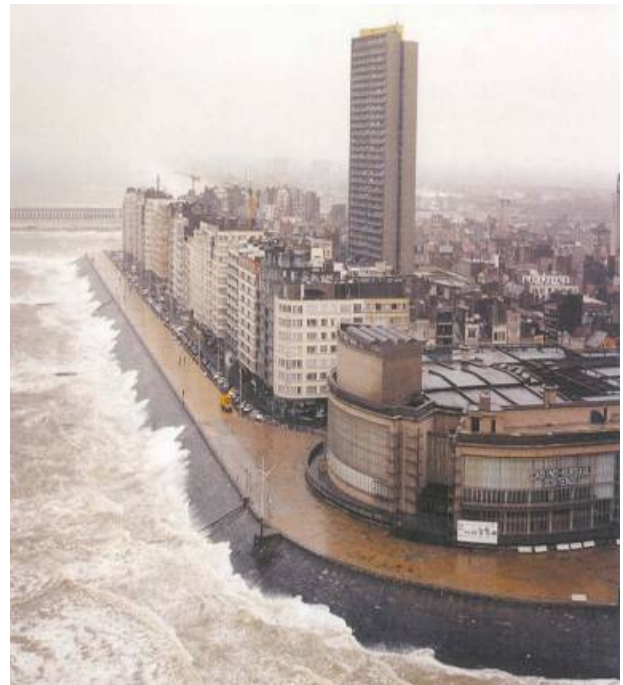

Figure 2. View on the seadike of Ostend before 2003 pier after a ship had a collision while entering the harbour.
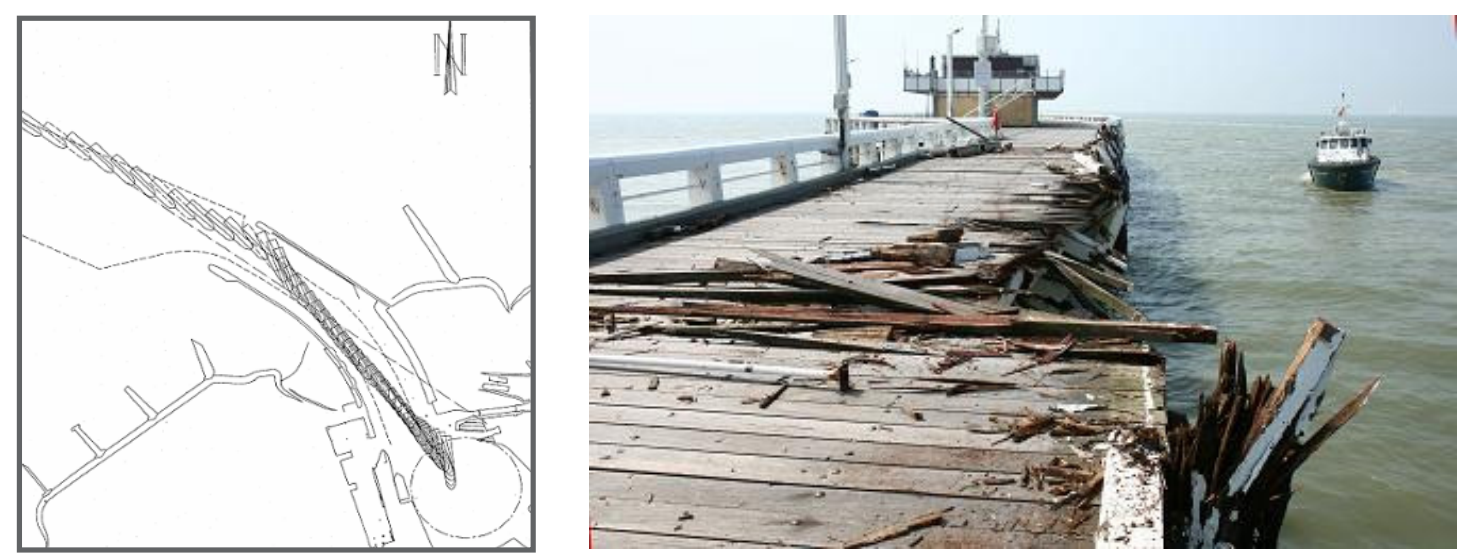

Figure 3. Navigation simulation of a ship entering the harbour of Ostend in the old situation (left) - Damage to the western pier after collision by a ship entering the harbour (right).

\section{History}

A first design sketch of a new harbour access was already made by the Maritime Access Division in 1997. A preliminary design followed in 1999 (Haecon n.v., 1999). In the following years, two construction permits were cancelled by action groups resulting in a 'tabula rasa' in 2003. The procedures had to start again from scratch at that moment, starting with the set up of a PlanEnvironmental Impact Assessment (Plan-EIA). Within the Plan-EIA, an alternative layout of the western breakwater, enclosing a large part of the seadike, was also studied but not chosen, see Fig. 4. End of 2007, the Plan-EIA was approved by the Flemish Government after which a project-EIA detailing the design of the western breakwater was made. The project-EIA was approved end of July 2009 and finally, the construction permit of the western breakwater was received in January 2010, concluding all administrative procedures.

In 2003, awaiting the necessary construction permits, the existing situation in Ostend was evaluated by a committee of experts. This committee concluded that the risk of flooding of Ostend city was too high (impermissible wave overtopping every 10-30 years) and that the stability of the dike was not guaranteed. As a provisional solution a beach nourishment of $800.000 \mathrm{~m}^{3}$ was performed in 2004, followed by a yearly re-nourishment of $80.000 \mathrm{~m}^{3}$. In this way a safety for the 100-year storm was foreseen, and the overtopping is reduced to less than $10 \mathrm{l} / \mathrm{s} / \mathrm{m}$. 
The final design of the new harbour access encloses two new breakwaters and the movement of the navigation channel, see Fig. 5. The new eastern and western breakwater have a length of approximately $800 \mathrm{~m}$ respectively $700 \mathrm{~m}$. The old navigation channel is represented in grey, the new navigation channel is turned more to the north and is represented in black. The navigation channel has a width of $150 \mathrm{~m}$ near Ostend, with an extra wide zone of $900 \mathrm{~m}$ long just outside the port (manoeuvring zone). To avoid sand to move from the final beach (which will provide safety to the 1000-year storm) to the navigation channel, a low crested breakwater will be constructed perpendicular to the northern part of the western breakwater.

In May 2007, the first works to realise the new harbour access started with the demolition of the eastern pier and the construction of a low (i.e. during high tide submerged) eastern breakwater (Fig. 6). The low eastern breakwater was constructed starting from an existing groyne in this first phase (explaining the kink in plan view). In this way a longer low breakwater could be built with the same quantity of material, leading to a more protected inner harbour during this phase of the works. In the beginning of July 2008 the low eastern breakwater was finished. The low eastern breakwater is incorporated then in a

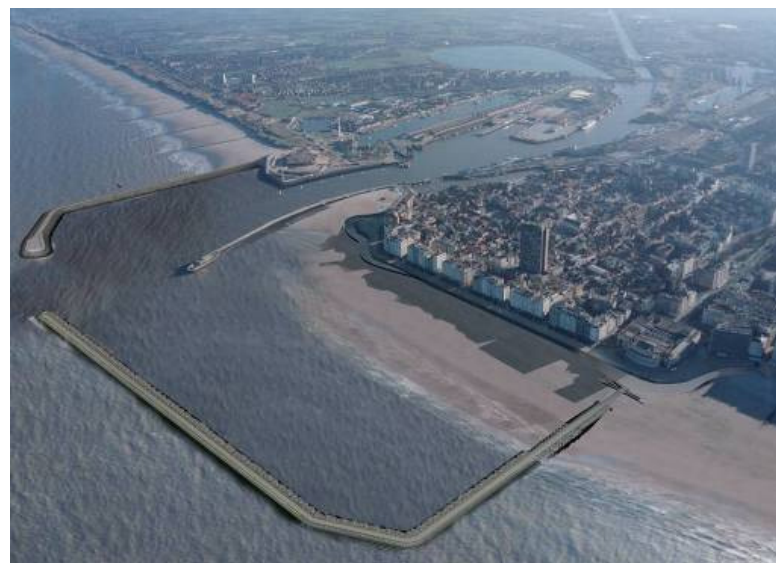

Figure 4. Artist impression of an alternative layout of the western breakwater studied within the project-EIA

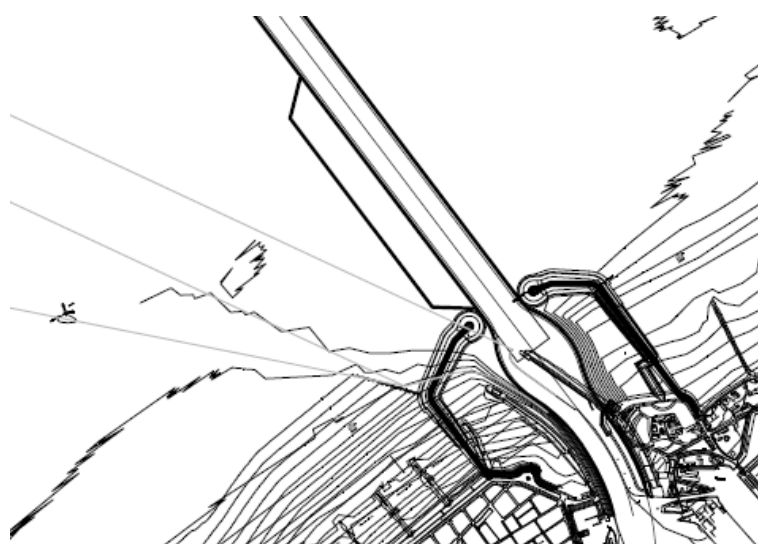

Figure 5. Final design of the new harbour access with old (grey) and new (black) navigation channel later stage in the final eastern breakwater.

The construction permits for the final eastern and western breakwaters were received on $20^{\text {th }}$ of May 2009 respectively $27^{\text {th }}$ of January 2010.
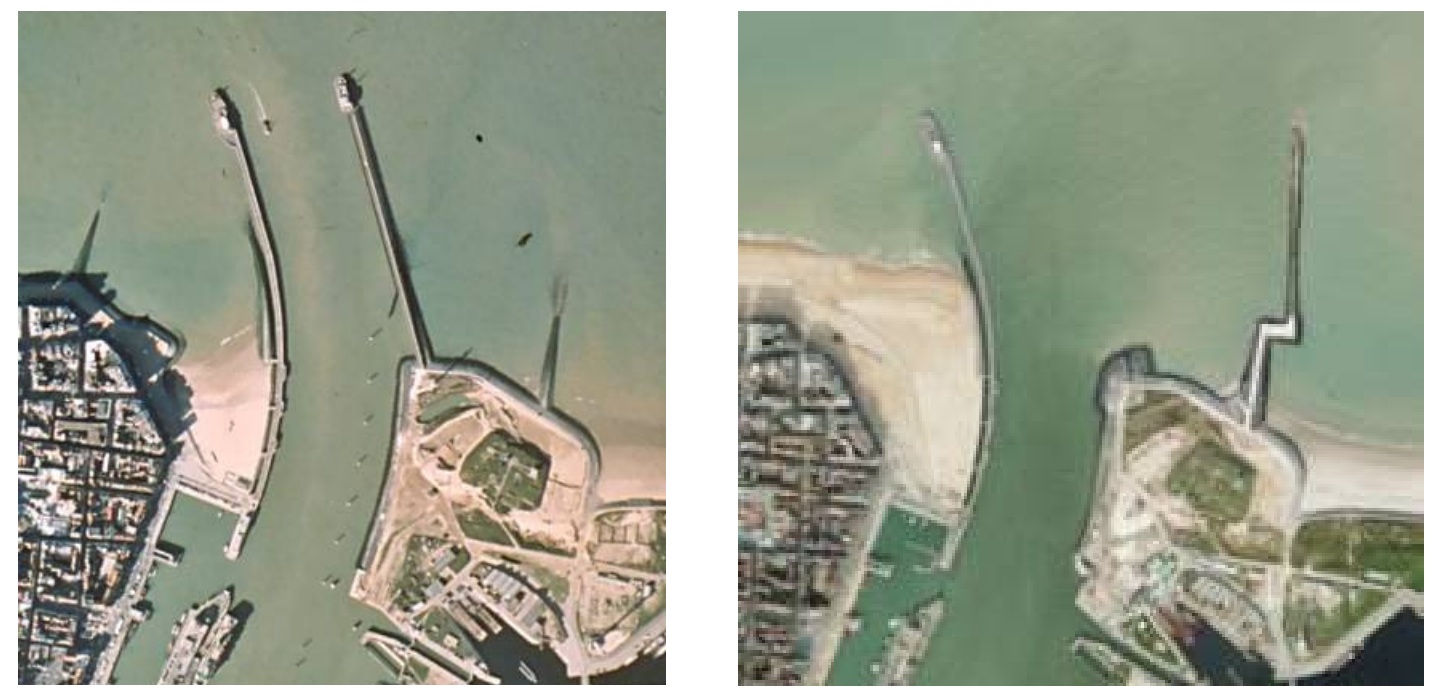

Figure 6. Old harbour access with eastern and western pier (left); first phase of new harbour access with low eastern breakwater (right) 
The first willow mattress of the eastern breakwater has been sunk down on $30^{\text {th }}$ of June 2009 . The construction of the western breakwater started in February 2010 with the placement of a layer of sea gravel over the full length of the breakwater.

The dredging works of the new navigation channel took place from 2008 to 2010. During the dredging works a lot of ammunition from World War I and II was found. The ammunition had to be treated very carefully, slowing down the dredging works. On March $19^{\text {th }} 2009$ a large mine was recovered (Fig. 7, left). At that moment it was decided to bring in the backhoe dredger 'Pinocchio' from DEME in order to reduce the risk of exploding. The backhoe dredger was mobilised from South Africa. For the dredging works in Ostend, it was equipped with a bucket of $21 \mathrm{~m}^{3}$. Fig. 7 , right, shows the 'Pinocchio' at work in Ostend.
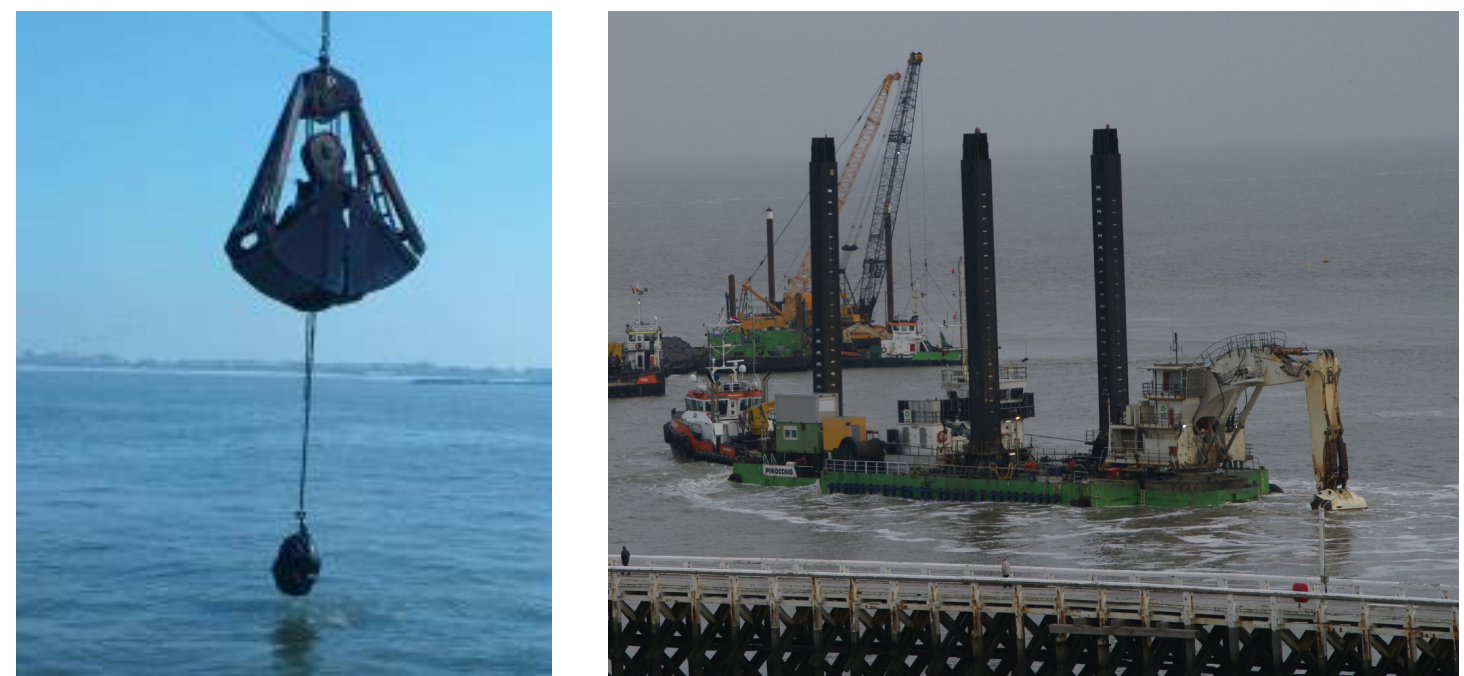

\section{Figure 7. Recovering of a large mine from World War 2 in Ostend (left); Backhoe dredger 'Pinocchio'} dredging in Ostend.

In June 2010 the dredging works of the new navigation channel were finished. However, on the first of February 2010, the new navigation channel already came into operation as the dredging works had progressed sufficiently at that moment.

\section{Studies}

During the design process of the new harbour access, many studies have been performed: nautical studies, hydraulic boundary studies, morphological studies, soil investigations, and studies on stability of the designed breakwaters.

\section{Nautical studies}

To find the 'best' lay-out of the breakwaters and access channel, nautical as well as morphological aspects were considered.

A flow model has been developed in Delft3D at Flanders Hydraulics Research (Flemish Community, Belgium) (Bijlsma, 2006). Fig. 8 shows the result of a flow calculation with the new breakwaters during maximum flood, spring tide (Verelst et al, 2009). The depth averaged velocity $(\mathrm{m} / \mathrm{s})$ is shown. The development of an eddy inside the harbour, having an impact on sedimentation into the harbour, is visible. Besides exchange of sediment filled water in an eddy, also the tidal filling of the port and density currents at the entrance will result in sedimentation of the harbour mouth and harbour. As the new breakwaters in Ostend are rather small (e.g. compared to the harbour of Zeebrugge), the sedimentation is expected to be reasonable. 


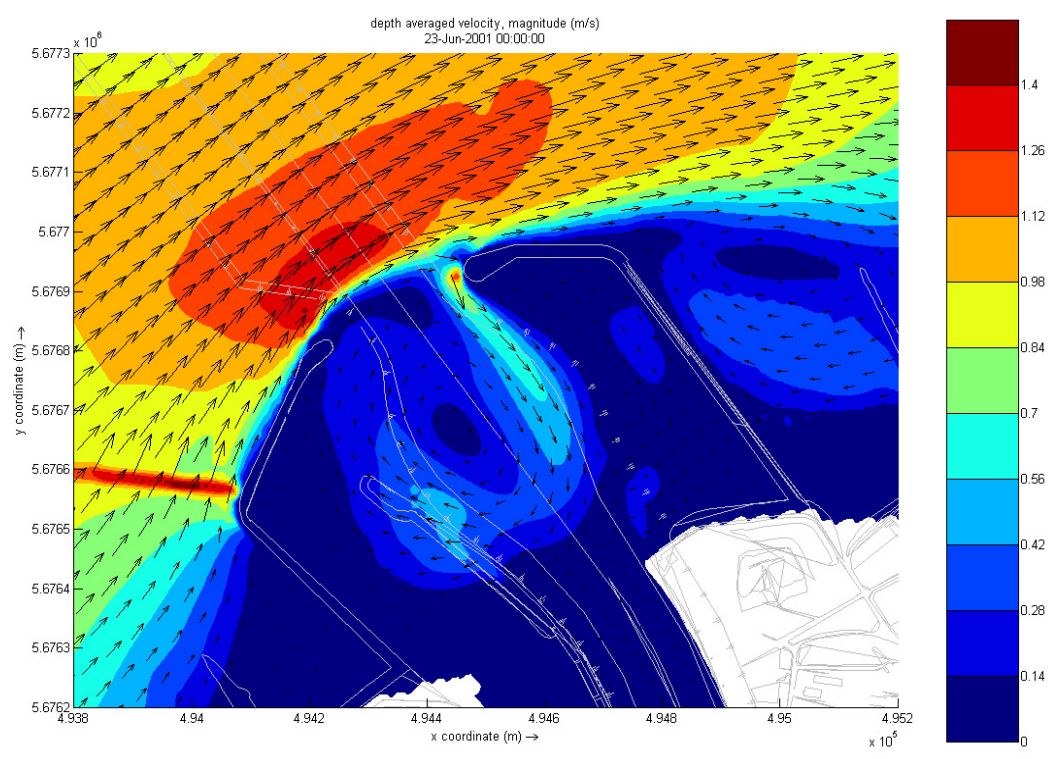

Figure 8. Flow field during maximum flood, spring tide for the new harbour design

Navigation simulations were performed at Flanders Hydraulics Research with different ships: a cargo ship (Length $\times$ Width $\times$ Draft $=144 \mathrm{~m} \times 20.4 \mathrm{~m} \times 6.5 \mathrm{~m})$, a roro-ferry $(\mathrm{LxWxD}=165 \mathrm{~m} \times 25.2 \mathrm{~m} \mathrm{x}$ $6.5 \mathrm{~m})$, a jumbo-ferry $(\mathrm{LxWxD}=182 \mathrm{~m} \times 28.5 \mathrm{~m} \times 7.3 \mathrm{~m})$ and a cruise ship $(\mathrm{LxWxD}=219.3 \mathrm{~m} \times 30.8 \mathrm{~m} \mathrm{x}$ $7.5 \mathrm{~m}$ ). Varying boundary conditions were considered: varying tide levels with corresponding currents, varying wind directions and forces. The width and depth of the access channel, and the available channel length within the new breakwaters, were designed in this way that the considered design ships can safely enter the harbour (some within specific current windows).

The statistical processing of navigation simulations with the cargo ship with specific boundary conditions is shown in Fig. 9 as an example. Besides the mean navigation route, also the navigation routes exceeded in $10 \%$ and $1 \%$ of the simulations are shown.

\section{Hydraulic boundary studies}

For the design of the breakwater sections, local hydraulic conditions and local soil conditions had to be studied. Starting from prototype measurement of waves at deep water, design waves were calculated considering a retour period of 100 years. Using the SWAN-model, design waves at the location of the new breakwaters were calculated. Energy supply by wind, depth-limited wave breaking, energy loss by bottom friction and whitecapping, redistribution of energy between wave components and depth- and flow refraction were taken

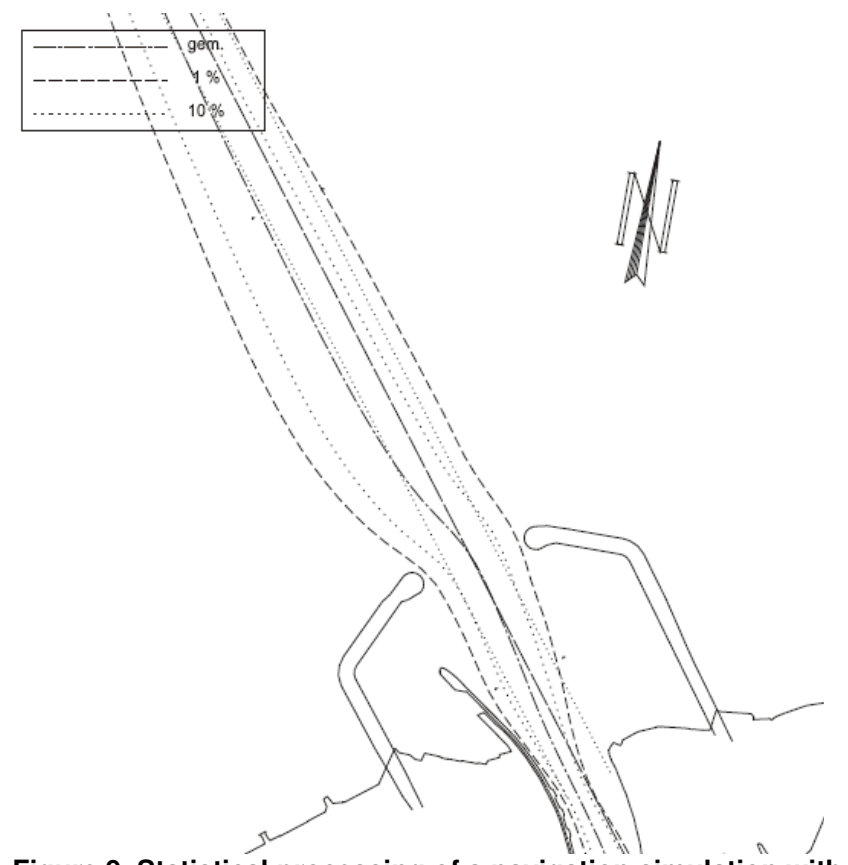

Figure 9. Statistical processing of a navigation simulation with a cargo ship

into account. Waves inside the harbour mouth were estimated using Simwave (Vanneste et al., 2008) and Goda-formula's. Fig. 10 shows a typical result of wave calculations inside the harbour mouth using Simwave. 


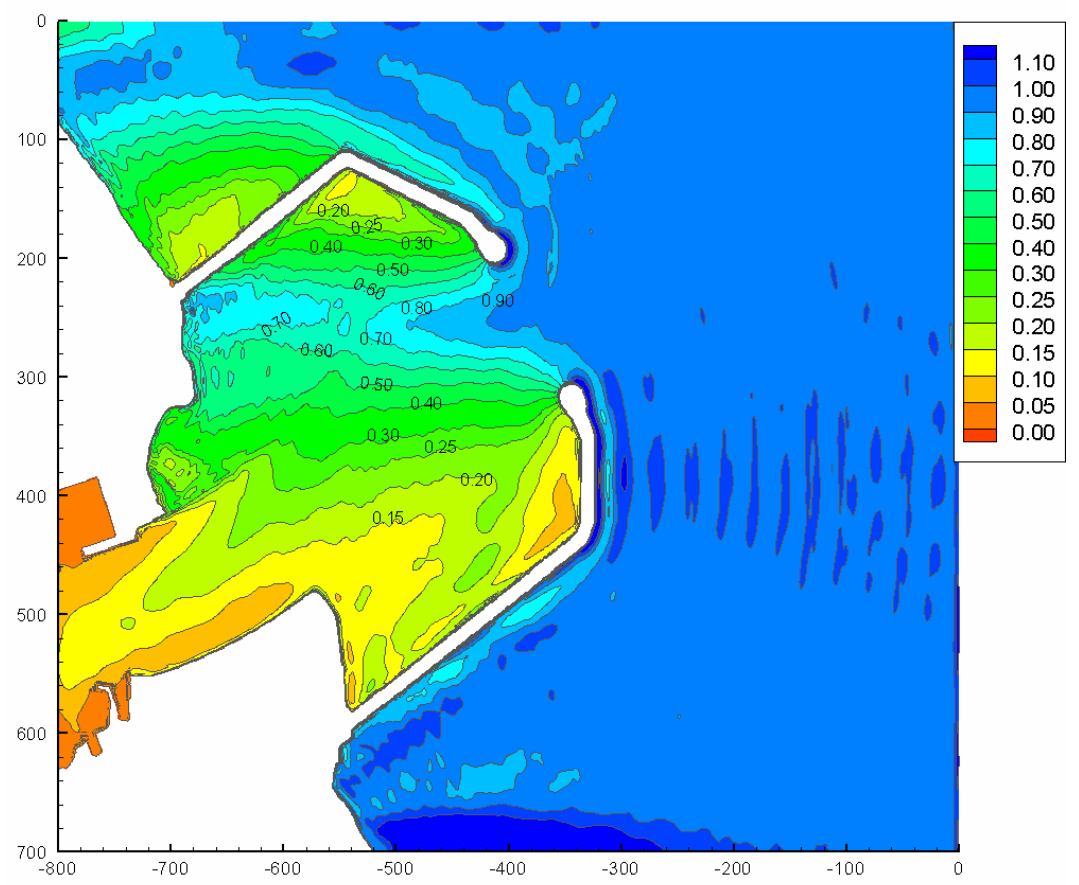

Figure 10. Wave calculation inside the harbour mouth using Simwave (Vanneste et al., 2008)

Also physical model tests were performed (Flanders Hydraulics Research), during which waves inside the harbour of Ostend were measured. Further prototype wave measurements at different locations inside the harbour of Ostend were used to calibrate the numerical and physical models.

The design waves at different locations on the western breakwater are shown in Table 1 (in which $\mathrm{P}$ "X" refers to the point on the axis of the western breakwater on a distance of " $\mathrm{X}$ " meter from the coast, measured on the axis of the breakwater).

\begin{tabular}{|c|cccc|}
\hline \multicolumn{5}{|c|}{ Table 1. Design waves for the western breakwater - sea side } \\
Location & $\begin{array}{c}\text { Water level } \\
\text { (mTAW) }\end{array}$ & Hm0 $(\mathrm{m})^{*}$ & $\mathrm{Tp}(\mathrm{s})$ & Wave direction \\
\hline P100 & +6.1 & $1.30(2.40)$ & 10.6 & $+/-70^{\circ}$ \\
P200 & +6.1 & $2.40(3.35)$ & 10.6 & $+/-70^{\circ}$ \\
P300 & +6.1 & $2.90(3.75)$ & 10.6 & $+/-70^{\circ}$ \\
P353 & +6.1 & $2.90(3.75)$ & 10.6 & $+/-70^{\circ}$ \\
P378 -P694 & +6.7 & 4.80 & 10.6 & all \\
${ }^{*}$ Hm0 with (without) final beach supply & & & \\
${ }^{* *}$ TAW $\sim 0.5 m$ LAT (Lowest Astronomical Tide) & \\
\hline
\end{tabular}

\section{Soil investigation}

An extensive soil investigation has been performed at the location of the new breakwaters. During several campaigns a lot of CPT's (Cone Penetration Tests) and borings were performed (see Fig. 11), and extensive laboratory testing has been carried out. Further geo-electrical research and sub-bottom profiling tests were performed. Finally historical research led to further insight into the soil characteristics.

The results of the CPT's and borings showed that the soil characteristics at the location of the northern part of the western breakwater (starting from the bend to the end of the western breakwater) are much worse compared to the rest of the western breakwater and to the eastern breakwater. Fig. 12 shows a typical CPT-result at the location of the eastern breakwater (left), and a typical CPT-result at the location of the northern part of the western breakwater (right). The upper layer of the latter one consists of soft sandy clay and loosely packed clayey sand. Study of all CPT's and borings at the location of the northern part of the western breakwater, learned that the thickness of the soft upper layer varies quite a lot even for CPT's close by each other. Typically the dense sand layer starts only at TAW $-16 \mathrm{~m}$ to TAW $-18 \mathrm{~m}$. 


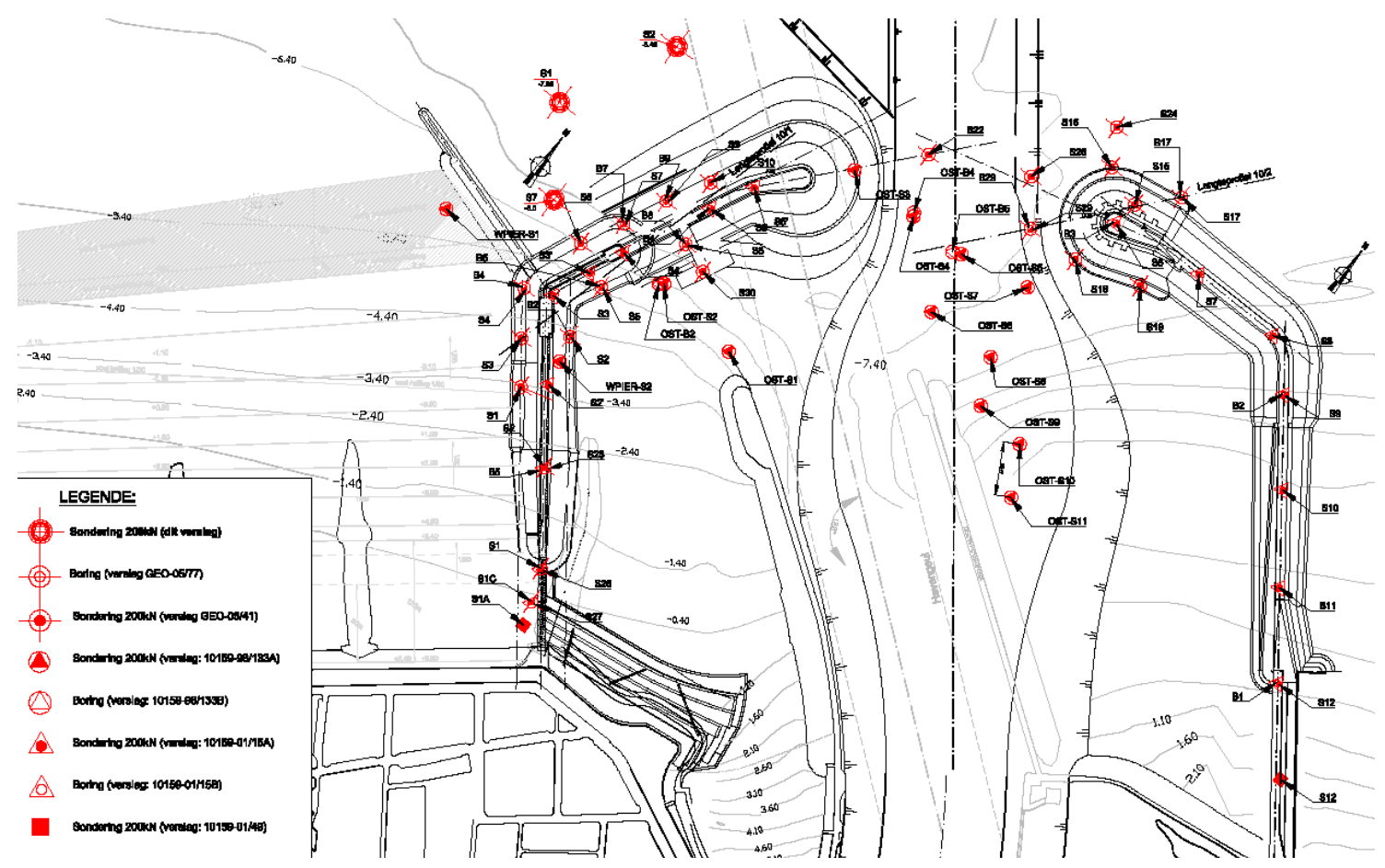

Figure 11. Overall view of location of CPT's and borings performed at the harbour of Ostend

Aiming to get a better view on the heterogeneity of the soil layers, geo-electrical research and subbottom profiling tests were performed. The tests were performed from a boat navigating at the location of the northern part of the new western breakwater.

During geo-electrical testing two electrodes are sending electric power into the bottom. Two potential electrodes in between are measuring the potential field. Based on the measured electric power, the measured electric potential and the known distances between the electrodes, the mean (apparent) resistivity can be determined up to a certain depth. As resistivity of sediment is mainly dependent of its porosity and the resistivity of the pore water, the measured resistivity should give an indication of the location of soft soil.
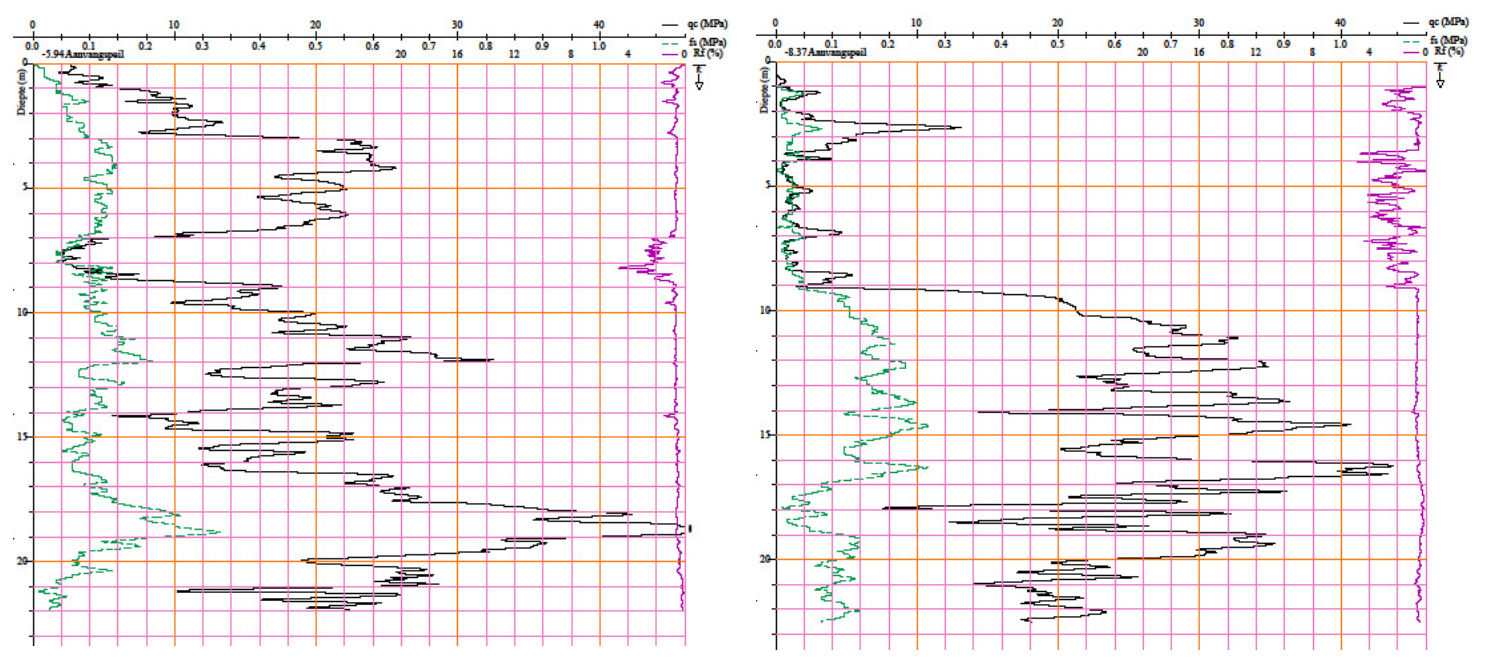

Figure 12. Typical CPT at the location of the eastern breakwater (left); Typical CPT at the location of the northern part of the western breakwater (right)

For sub-bottom profiling tests low-frequency acoustic sounds are used. These are reflecting on different layers in the bottom and on objects with deviant density of the surrounding area. The degree of absorption of different frequencies gives an indication of the bottom structure. 
The results of both methods, geo-electrical tests and sub-bottom profiling tests, were rather poor for this investigation, little agreement was found with the CPT's and borings. The large heterogeneity of the bottom may be a reason for this.

An explanation for the very heterogeneous soil layers at the location of the northern part of the western breakwater has finally been found by historical research. Some 25 years ago, dredging works at the (former) access channel were performed using a suction dredger. In this way 'good' sand from deeper soil layers was collected and could be used in other projects. However, in this way, large holes were made in the sea bottom. These holes were filled with soft material through the years. As can be seen on Fig. 5, the former access channel crosses exactly the northern part of the new western breakwater.

\section{Stability}

Making use of the local hydraulic conditions and the local soil conditions, the local and overall stability of the newly designed breakwaters have been tested.

A typical cross-section of the northern part of the western breakwater is shown in Fig. 13.

The bottom level is situated at about TAW $-8.5 \mathrm{~m}$. To save the amount of rubble mound needed for the core of the breakwater, the sea bed has been raised with $4 \mathrm{~m}$ of sea gravel in the middle. The first $1 \mathrm{~m}$ of sea gravel is meant to compensate for expected settlement of the subsoil during construction. On this gravel, willow mattresses with geotextiles are placed over the full width of the breakwater. Underneath the berms of the breakwater, the geotextile serves mainly as a filter, i.e. it avoids fine material to disappear from the bottom through the berm. In the middle of the northern part of the western breakwater, a very strong so called 'super-geotextile' is used, which also serves as 'armouring' of the breakwater, to cope with the weak soil characteristics at that location. The core of the breakwater consists of rubble mound, $15-300 \mathrm{~kg}$. The filter layer consists of rubble mound 1-3 tonnes and 0.3-1 tonnes at sea side respectively harbour side. The berms of the breakwater consist of rubble mound 3-6 tonnes. The armour layer of the breakwater consists of 2 layers of 15t HAROs at sea side and a double layer of 3-6 tonnes armour stone at lea side. The slope of structure is 1/1.5.

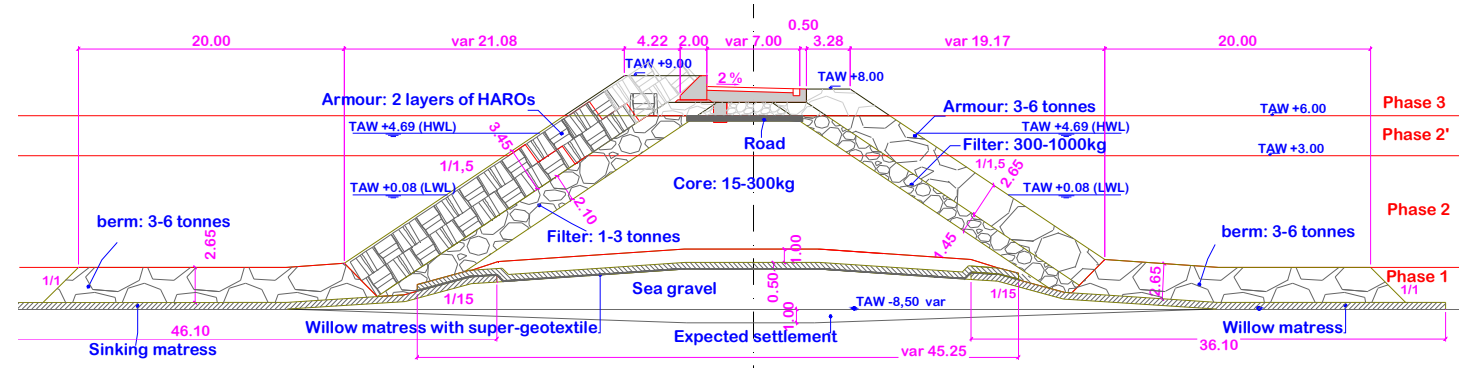

Figure 13. Typical cross-section of the northern part of the western breakwater

On Fig. 13 the different construction phases of the western breakwater are shown (red lines). During the first phase, the sea gravel, the willow mattresses and the berms are placed. During the second phase, the breakwater is built up to TAW $+3 \mathrm{~m}$. During the third phase, called phase 2', the breakwater is constructed up to TAW $+6 \mathrm{~m}$. And in the last phase, phase 3 , the breakwater is completed.

The stability of the armour layers of the breakwater, both sea side and harbour side, and the stability of the crest element have been tested in a wave flume (physical model, scale 1/30) at Ghent University (Belgium). As the crest level of the structure is rather low compared to the design water level (TAW +8 or $+9 \mathrm{~m}$ compared to TAW $+6.7 \mathrm{~m}$ ), overtopping is high during the design storm. This resulted in a special shaped crest element (with chamfered part a sea side and a 'tooth' every $7 \mathrm{~m}$ ) and a rather heavy armour layer at harbour side of 3-6 tonnes.

Further overall slope stability analysis has been performed using the software codes Geoslope and Plaxis. Geoslope is a software code based on the use of vertical slices where deformations are not considered. Plaxis is a finite element method which also allows to calculate settlements. Prototype 
settlement measurements of the northern part of the breakwaters are going on during construction, aiming to validate the numerical calculations.

Economical reasons are at the basis of the choice using a super-geotextile to deal with the thick soft soil layer underneath the northern part of the western breakwater. The super-geotextile is designed in this way that a stable breakwater is obtained, during construction phases as well as when the breakwater is finished. The slope stability analysis in Geoslope and Plaxis resulted in a super-geotextile with a nominal tensile strength of $1600 \mathrm{kN} / \mathrm{m}$ in transverse direction of the breakwater and $250 \mathrm{kN} / \mathrm{m}$ in the direction of the breakwater. The calculations showed that the construction phase 2' is the most critical phase.

The use of a super-geotextile to strengthen the soil does not avoid the soil to settle. Plaxis calculations resulted in an overall final settlement of approximately 1 to $1.3 \mathrm{~m}$. As the breakwater is built in several phases, large part of the settlements will occur (and be compensated) during construction. Calculated settlements are tried to be validated by the installation of 3 piezometers at different locations on the northern part of the western breakwater during the first construction phase.

The piezometers were each fixed on a concrete block which was placed on the sea gravel. First measurements of the three piezometers are shown in Fig. 14. PB5, PB7 and PB9 refer to the three piezometers. Tidal variations are filtered out of the signals. The black 'mean' lines show the increase of water column or the settlement at the location of each piezometer. The scattering of the signals around the black line originates from the waves. On the graph also the measured waves just in front of Ostend are represented. This allows explaining the 'jump' in the settlements: most probably this refers to the settlement of the concrete blocks itself during the storm. A mean settlement of approximately $5 \mathrm{~cm}$ is measured during this month.

The piezometers were removed to place the willow mattresses and immediately after placed back onto the structure. It is aimed for to further measure settlements during construction of the breakwater. Once above water level, settlements will be easier to measure by installation of a fixed plate into the structure.

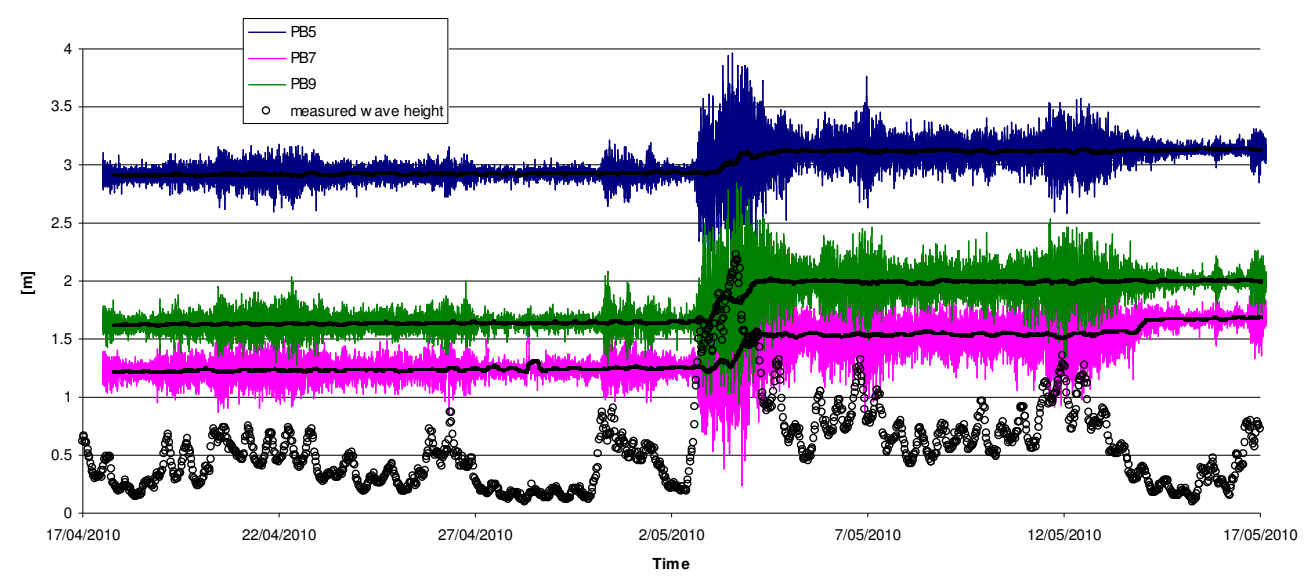

Figure 14. Settlement measurements at the northern part of the western breakwater after finishing phase 1

For detailed information on the overall slope stability analysis of the new breakwaters is referred to De Rouck et al. (2010).

\section{Architecture}

During the last construction phase, phase 3 , the breakwaters will be completed. A walkway at level TAW $+7 \mathrm{~m}(+8 \mathrm{~m}$ at the heads) allows tourists to walk on the breakwaters. On the eastern breakwater a new radar mast will be placed. An artist impression of the new radar mast on the head of the eastern breakwater is shown in Fig. 15 (view from sea to the coast). On the western breakwater the walkway will end in an open place. A cross-section of the head of the western breakwater is shown in Fig. 16. Stairs create the transition from the crest element to the walkway, creating a kind of stand, a protected location in the middle of a huge space. 


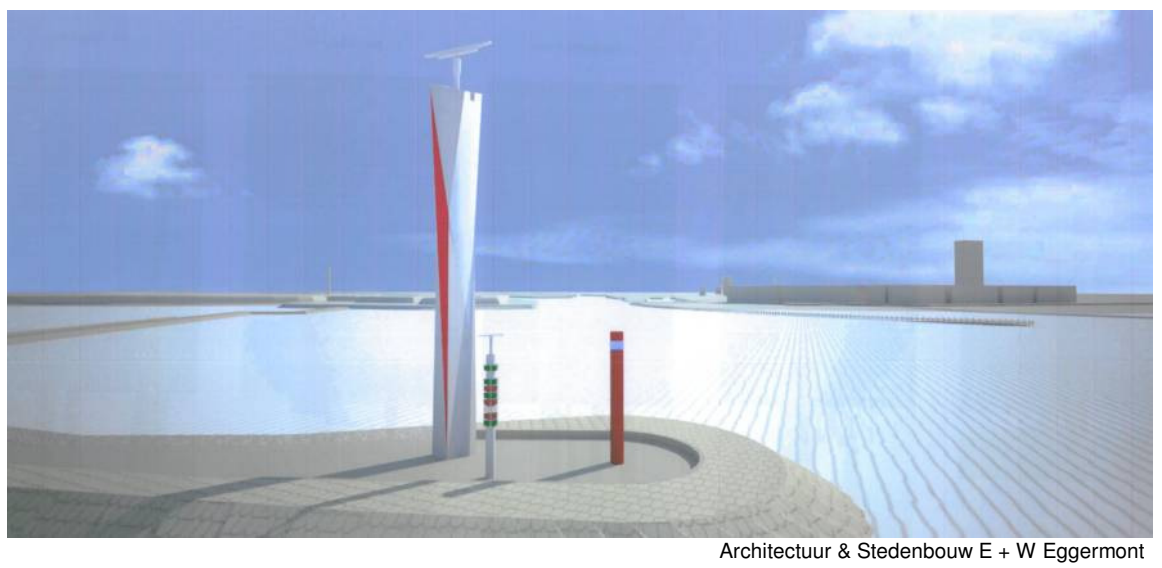

Figure 15. Artist impression of the new radar mast on the eastern breakwater

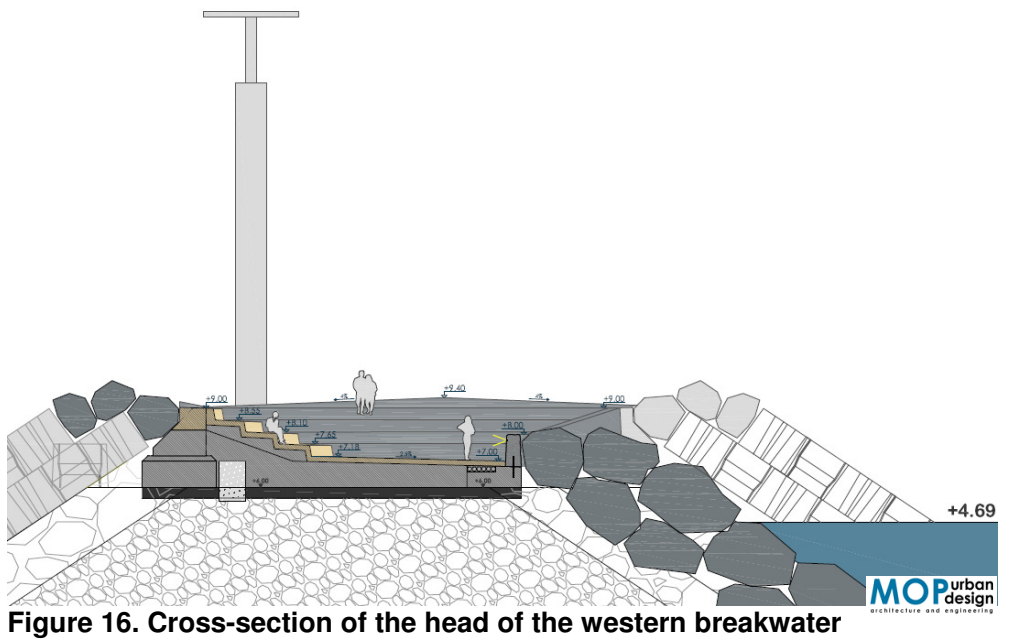

\section{CONSTRUCTION WORKS}

The contractor concerns the temporary trading association 'Stene-Twins', consisting of three parties: Dredging International n.v., Depret n.v. and Herbosch-Kiere n.v..

The first works enclosed the construction and placement of the willow mattresses for the eastern breakwater. Fig. 17 shows a picture of the construction of a willow mattress on site.

The mattresses have a width of $30 \mathrm{~m}$ and a length from 20 up to $55 \mathrm{~m}$. The mattresses were constructed by hand and consist of 4 shranked layers of willow bundles placed on each other, fixed with ropes to the geotextile. Between the first 2 layers of willow bundles, loose willow branches are placed to avoid damage to the geotextile when placing rubble mound on top of the matresses. Geotextiles from Stabilenka® (Huesker) have been used.

For the western breakwater, a super-geotextile was needed. It has a tensile strength of $1600 \mathrm{kN} / \mathrm{m}$ in transverse direction of the breakwater, and $250 \mathrm{kN} / \mathrm{m}$ in the direction of the breakwater. 
In total approximately $105.000 \mathrm{~m}^{2}$ willow mattresses were manufactured.

The willow mattresses were towed into the water and sunk down using $300 \mathrm{~kg} / \mathrm{m}^{2}$ rubble mound 10 $60 \mathrm{~kg}$, see Fig. 18. Immediately after $300 \mathrm{~kg} / \mathrm{m}^{2}$ rubble mound $60-300 \mathrm{~kg}$ was placed on it. As during peak of the tide currents up to $1.2 \mathrm{~m} / \mathrm{s}$ are measured, the sinking of the mattresses had to be performed just at the turn from high to low tide or vice versa.

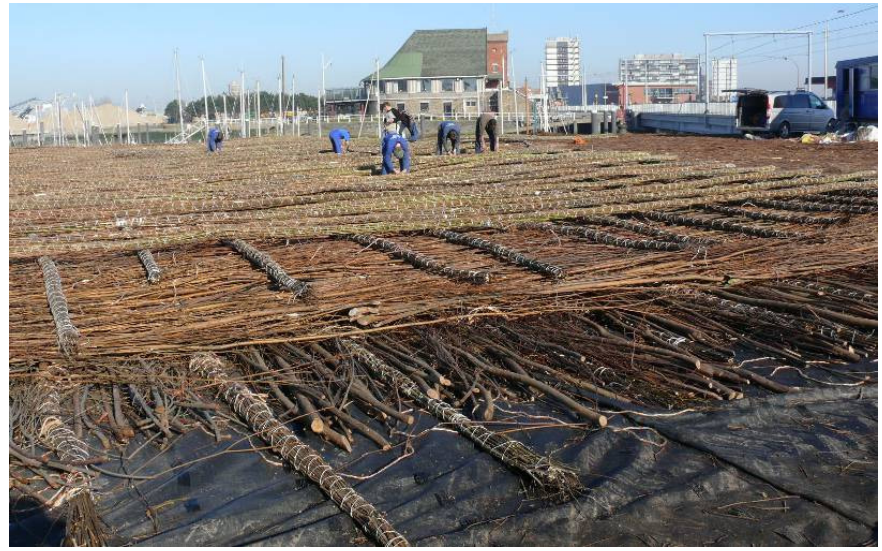

Figure 17. Construction of a willow mattress on site
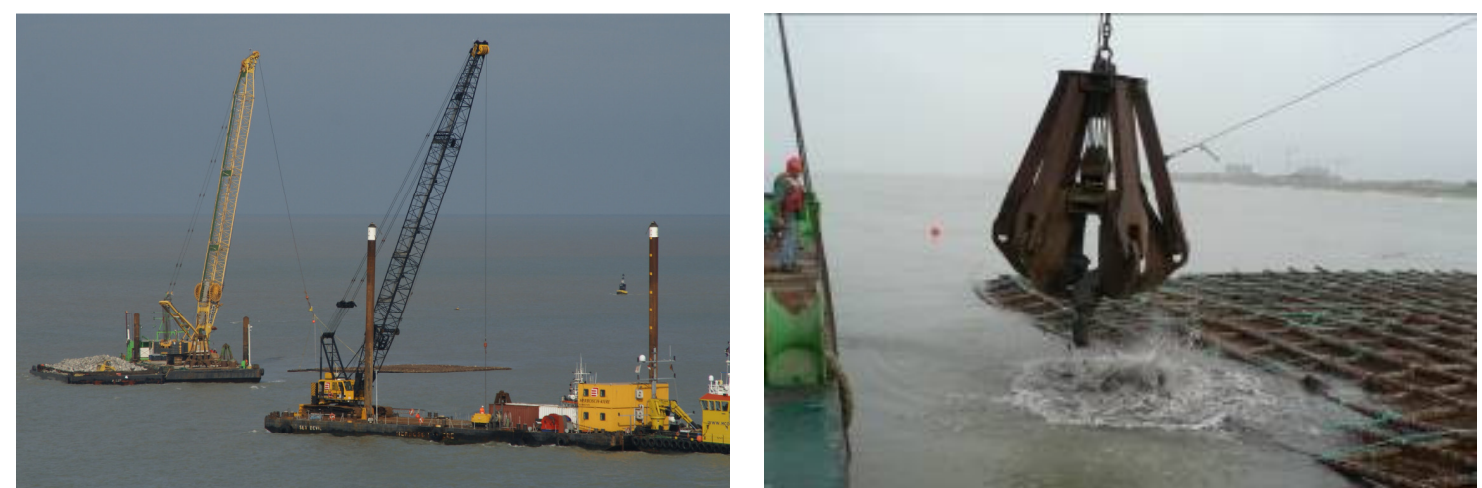

Figure 18. Positioning of the willow mattress at sea (left); Sinking down of the willow mattress by placement of $300 \mathrm{~kg} / \mathrm{m}^{2}$ rubble mound $10-60 \mathrm{~kg}$ (right)

After placement of a willow mattress, a multibeam measurement was performed to check the exact position of the willow mattress. Fig. 19 shows a result of such a multibeam.

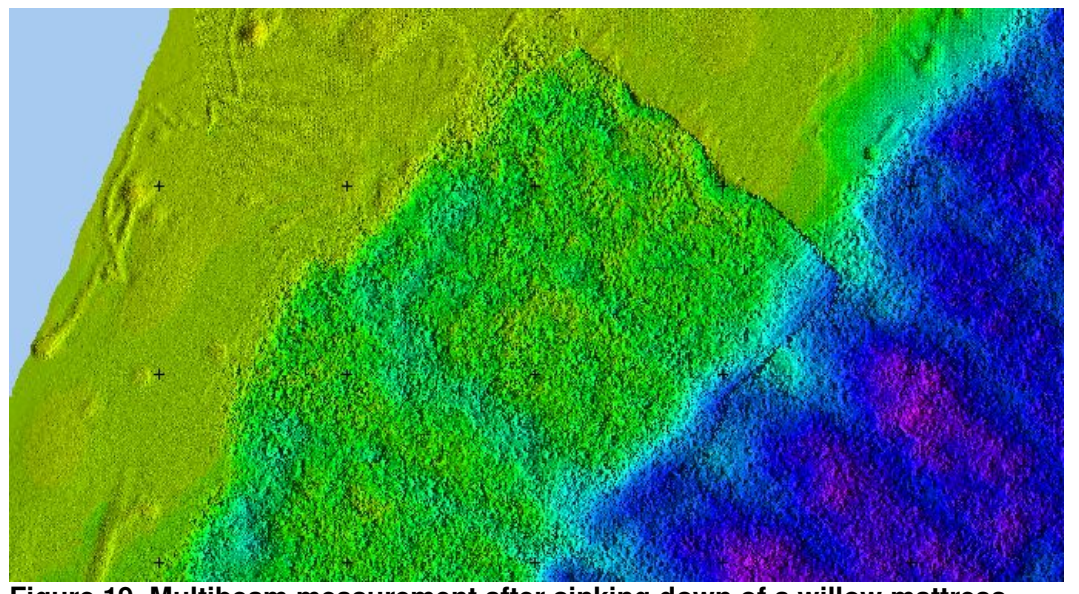

Figure 19. Multibeam measurement after sinking down of a willow mattress

For the construction of both eastern and western breakwater, a total amount of 140.000 tonnes of sea gravel and 810.000 tonnes of quarry rock is needed.

The quarry rock concerns several gradations: $10-60 \mathrm{~kg}$ and $60-300 \mathrm{~kg}$ for placement on the willow mattresses; $15-300 \mathrm{~kg}$ for building the core of the breakwaters, $300-1000 \mathrm{~kg}$ for the filter layer; $1-3$ tonnes for construction of berms and also filter layers, and 3 - 6 tonnes for construction of berms and armour layers.

The quarry rock is mainly exploited from stone quarries 'Les Carrières de la Pierre Bleue Belge (Soignies, Belgium)', 'Carrières du Hainaut (Soignies, Belgium)', 'Calcaires de la Sambre (Landelies, Belgium)', 'Dudman Group Ltd (South England, United Kingdom)'. 

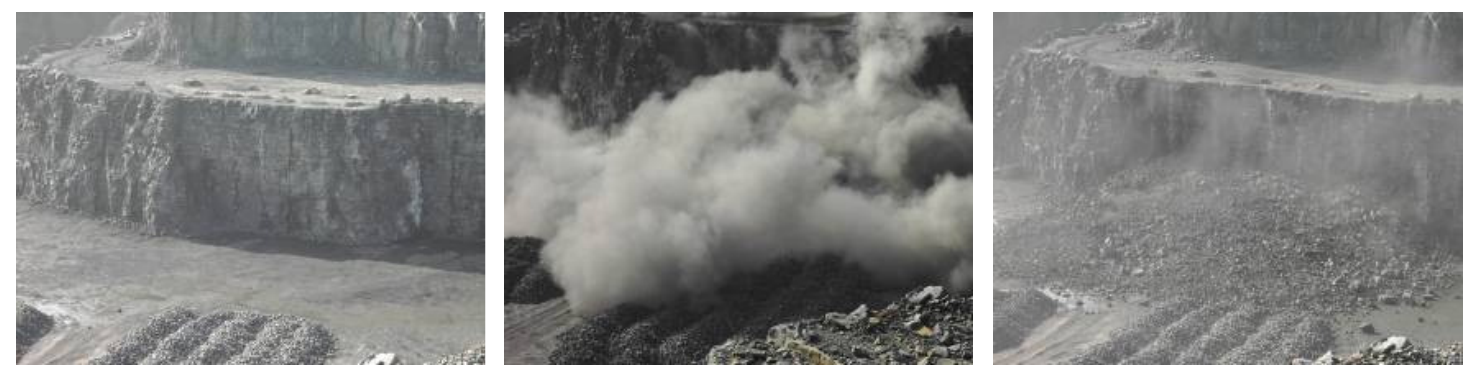

\section{Figure 20. Exploitation of quarry rock in a stone quarry.}

Fig. 20 shows a series of pictures during exploitation of the rock. On Fig. 21 the sorting out of the rock in the stone quarry is shown.

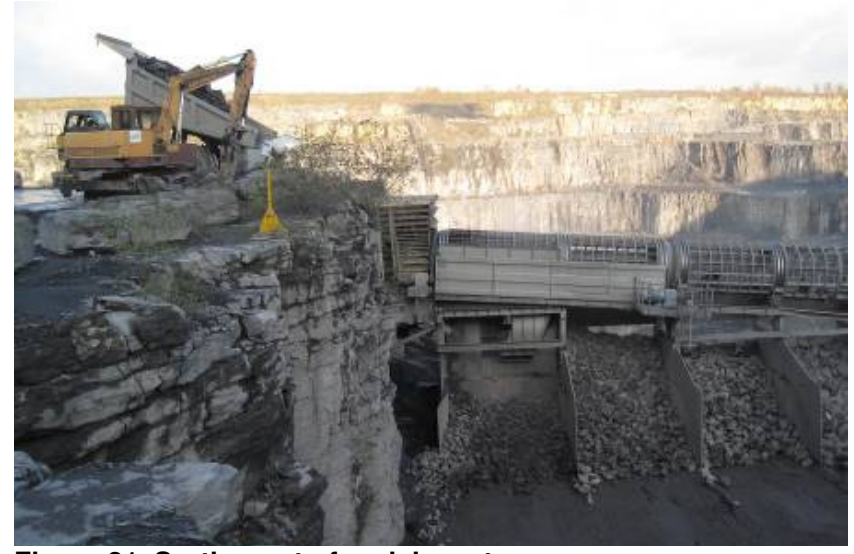

Figure 21. Sorting out of rock in a stone quarry

After sorting out the rock, the wanted rock gradations are created by composition of specific rock sizes. The quarry rock is then transported to Ostend by truck or by boat.

Fig. 22 shows a crane placing the berms of the most seaward part of the eastern breakwater, taking rocks of 3-6 tonnes from a pontoon.

After finishing placement of the willow mattresses and the berms, the breakwaters are constructed, per phase, starting at land, moving seawards. The core and filter are constructed each time some ten meters forward, but in this way that protection of the structure by placing its armour layer is still possible when bad weather (high waves) is predicted. Fig. 23 shows a cable crane placing the filter layer of 1-3 tonnes on the eastern breakwater.

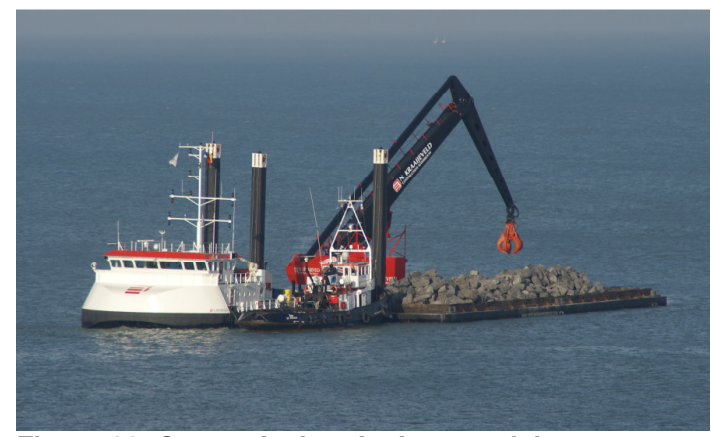

Figure 22. Crane placing the berms of the eastern breakwater.

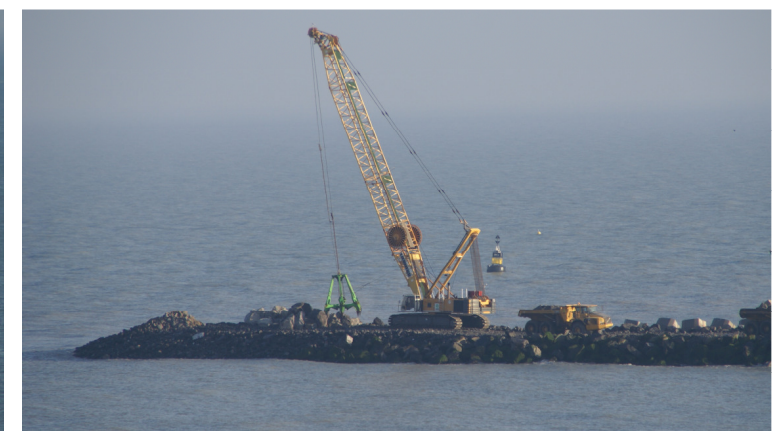

Figure 23. Cable crane placing the filter layer on the core of the eastern breakwater.

The seaside armour layer of the breakwaters consists mainly of a double layer of HAROs. The HARO was developed in Belgium and concerns a hollow concrete unit (Fig. 24). The HAROs used in Ostend each have a weight of 15 tonnes and are $1.68 \mathrm{~m}$ high. In total 5.100 HAROs are constructed. The HAROs are fabricated and stacked on an industrial zone near Ostend city. Afterwards the HAROs are 


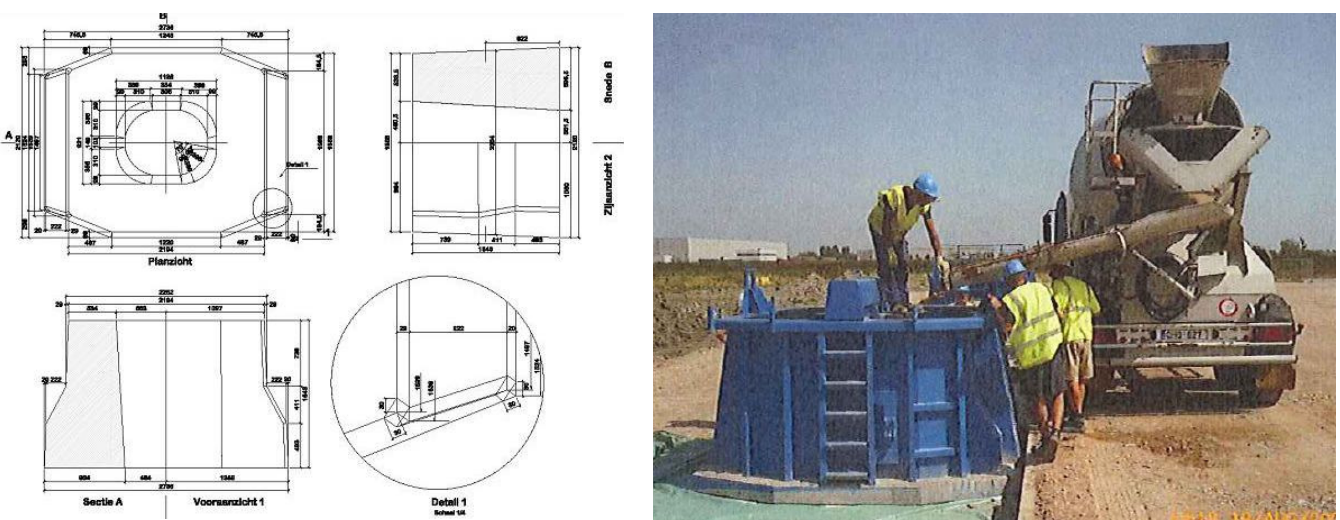

Figure 24. Dimensions of the HARO (a); Casting of a HARO (b)

transported to the working site by means of pontoons and finally moved to the breakwaters by trucks. Fig. 25 shows the HAROs stacked before placing on the breakwaters.

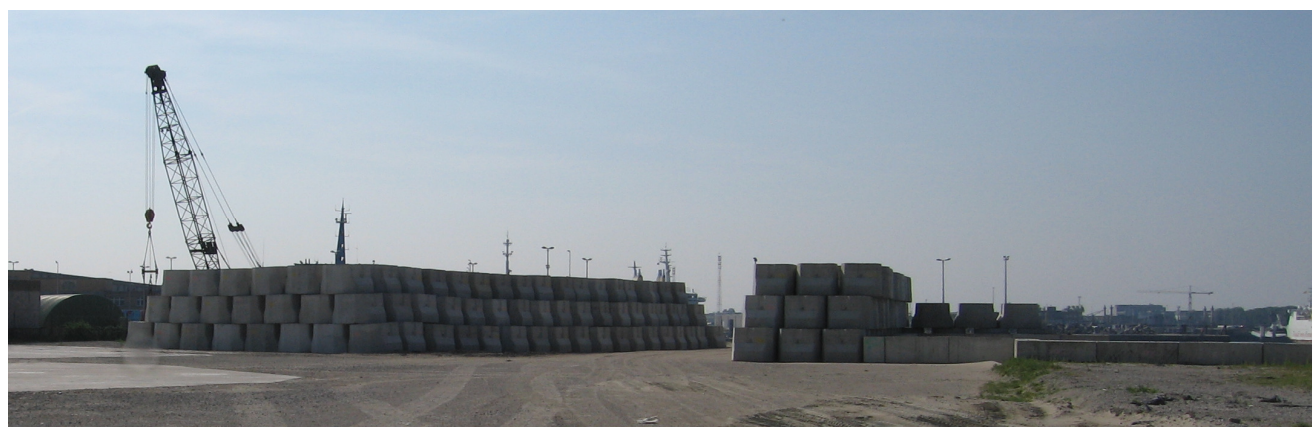

Figure 25. Stacking of the HAROs before processing into the breakwaters

The HAROs are placed on the breakwaters using an especially designed grab, see Fig. 26. Fig. 27 shows a picture of the placement of HAROs on the eastern breakwater.

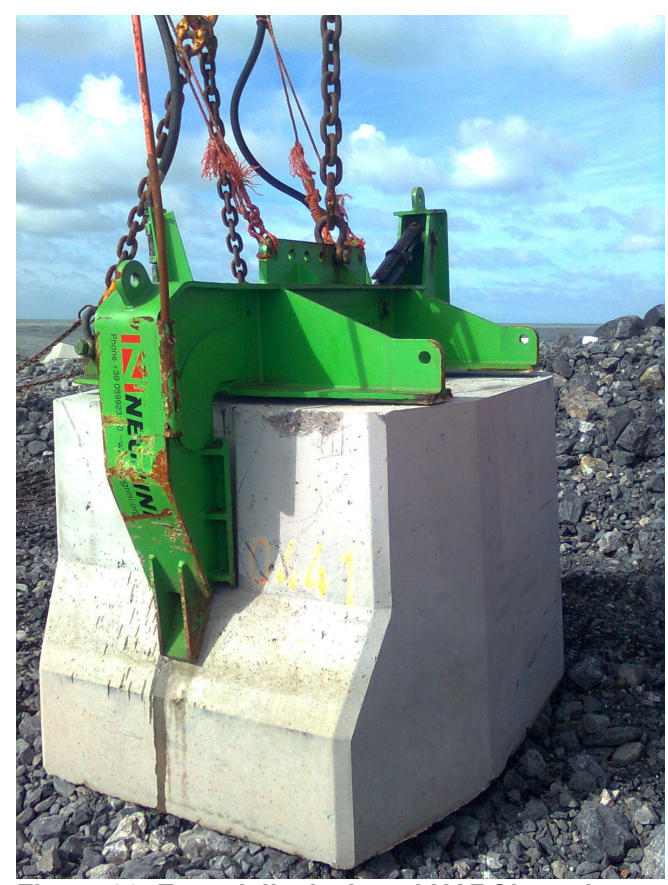

Figure 26. Especially designed HARO's grab.

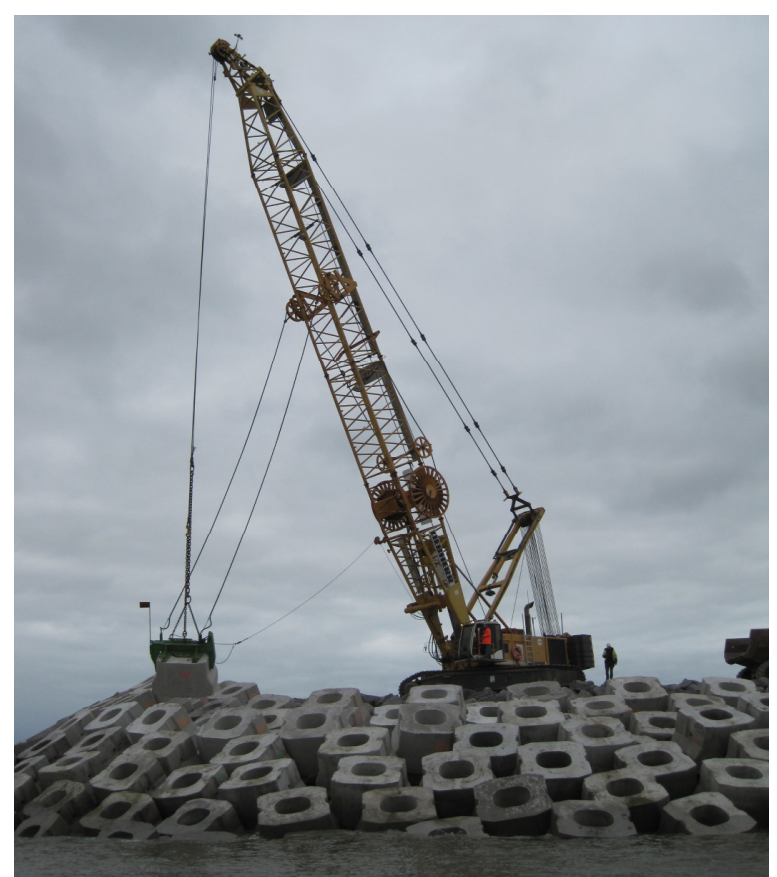

Figure 27. Placement of the HAROs on the breakwater slope. 


\section{FUTURE DEVELOPMENTS}

The construction works of the breakwaters started in 2008, and phase 1, phase 2 and phase 2' of both breakwaters will be completed in summer 2012. Following on this, phase 3 will be started. Depending on the remaining settlement of the northern part of the western breakwater at that moment, the finishing of this part will take some time longer.

At this moment (October 2010) the eastern breakwater is almost finished up to level TAW+6m. Also the first phase of the western breakwater is almost finished.

Fig. 28 shows 3 pictures of the situation in September 2010. The placement of HARO's on the eastern breakwater is ongoing. As the constructions works of the first phase of the western breakwater are mainly below water level, only a small part of the western breakwater near the beach is visible on the pictures below.
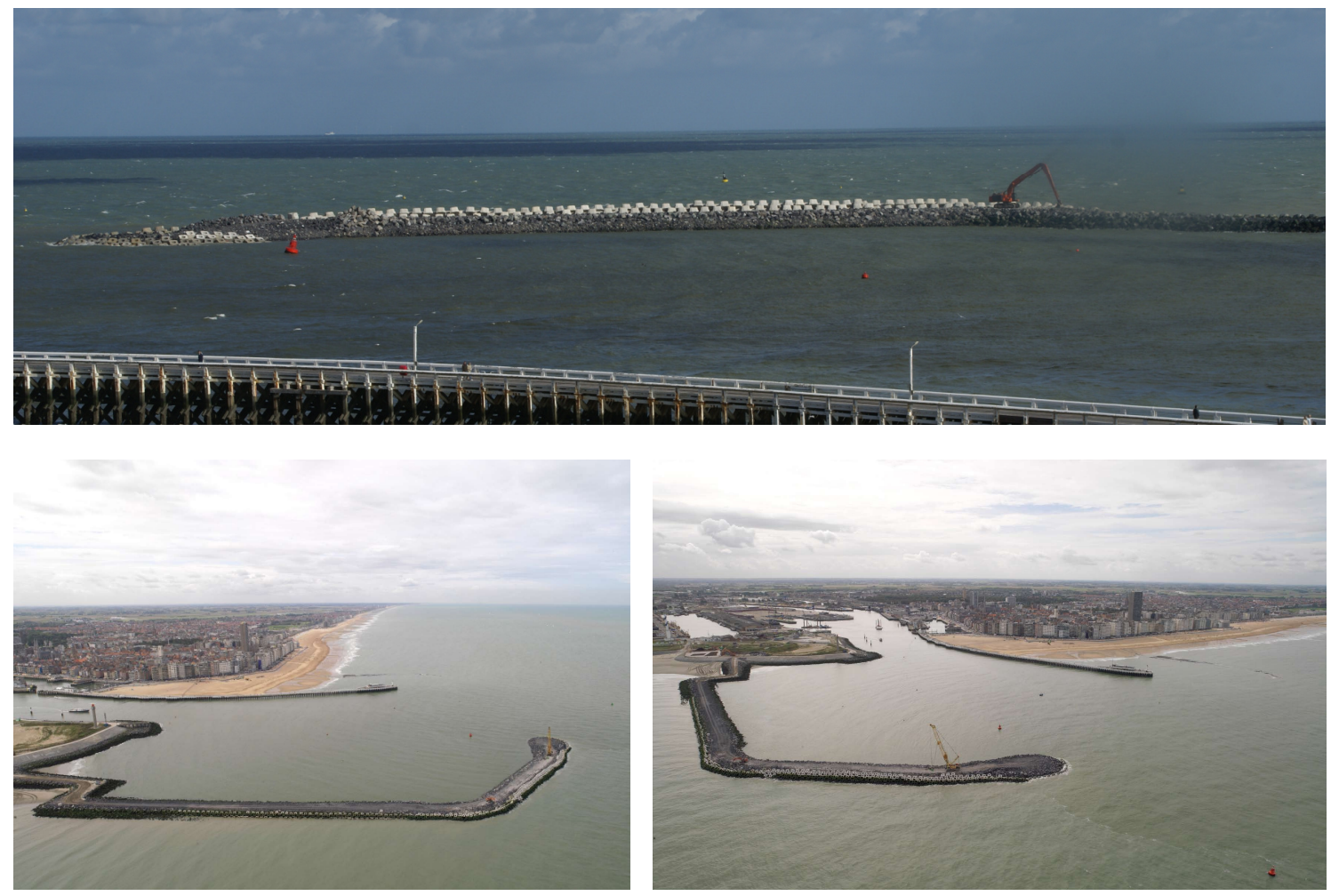

Figure 28. View on the most seaward part of the eastern breakwater (above); Aerial view on the construction works (below)

\section{REFERENCES}

Bijlsma, A. 2006. Haven van Oostende - Studie nieuwe haventoegang Onderzoek van de HLES methodiek van Delft3D - FLOW voor de haven van Zeebrugge.

De Rouck, J., Van Doorslaer, K., Goemaere, J., and H. Verhaeghe. 2010. Geotechnical design of breakwaters in Ostend on very soft soil, Proceedings of $32^{\text {nd }}$ International Conference on Coastal Engineering, ICCE 2010, ASCE.

Haecon n.v. - Bovyn K., De Rouck J., and T. De Mulder. 1999. Oostende nieuwe havenmond, verruiming nautische toegang, tender document.

Vanneste et al. 2008. Design of Oostende Harbour: Numerical Simulation of Wave Propagation Inside Area Breakwaters, report DBO107/88a, Ghent University, Belgium. 
Verelst, N., Delgado, R., Janssen, J., Verwaest, T., De Mulder, T., and F. Mostaert. 2009. Hydraulische simulaties voor verschillende varianten van de westelijke dam met een verfijnd Oostende - model: Eindrapport, WL Rapporten, 627_14, Waterbouwkundig Laboratorium, Antwerpen, België. 